43-44 | 2013

Le pastoralisme en Haute-Asie : la raison nomade dans l'étau des modernisations

\title{
Transformation of high altitude livestock-keeping in China's mountainous western periphery
}

Transformations de l'élevage d'altitude dans les régions de montagne de l'ouest de la Chine

\section{Hermann Kreutzmann}

\section{(2) OpenEdition}

Journals

Édition électronique

URL : https://journals.openedition.org/emscat/2141

DOI : 10.4000/emscat.2141

ISSN : 2101-0013

Éditeur

Centre d'Etudes Mongoles \& Sibériennes / École Pratique des Hautes Études

Référence électronique

Hermann Kreutzmann, «Transformation of high altitude livestock-keeping in China's mountainous western periphery ", Études mongoles et sibériennes, centrasiatiques et tibétaines [En ligne], 43-44 | 2013, mis en ligne le 20 septembre 2013, consulté le 13 juillet 2021. URL : http://journals.openedition.org/ emscat/2141; DOI : https://doi.org/10.4000/emscat.2141

Ce document a été généré automatiquement le 13 juillet 2021.

(c) Tous droits réservés 


\section{Transformation of high altitude livestock-keeping in China's mountainous western periphery}

Transformations de l'élevage d'altitude dans les régions de montagne de l'ouest de la Chine

Hermann Kreutzmann

\section{Introduction}

1 High Asia, stretching from the Pamirs to the Tibetan Plateau, can be perceived as a region of similar ecological properties and assets when it comes to pastoral practices and available options for the utilisation of locally available resources. Pastures and rangelands are to be found in high elevations, often above $3500 \mathrm{~m}$ altitude. The extent and size of pastures varies significantly. A highly complex system of adapted pastoralism strategies has been developed over centuries, characterised by a multiseasonal approach and with a high degree of regional variation. Change has come with great force in recent years. Resettlement schemes in China, new pasture laws in Kyrgyzstan and Tajikistan, and less administrative interference in Afghanistan and Pakistan characterise the different approaches and outcomes of pastoral practices to date in a similar ecological environment that some describe as a boon to human survival in a challenging periphery and others as a degraded eco-system that needs proper attention.

2 The area under survey is also an important yak-breeding area where different techniques and strategies are applied. The spectrum is rather wide considering that farmers and pastoralists in the Afghan Hindukush and Pamir are yak-breeders without any external support and basically dependent on their own skills and exchange networks, while their colleagues in China are supplied with extension services and experience significant governmental interference on the path to modernisation, as in Tibet, Qinghai, Inner Mongolia and Xinjiang. The purpose of this paper is to draw 
attention to the variations in human responses to the challenges and constraints posed by a socio-political environment in a comparatively homogeneous ecological setup characterised by harsh climatic conditions. Our area of reference is the yak-breeding zone of Western High Asia (fig. 1) and the Tibetan Plateau. Besides yaks, other important livestock such as Bactrian camels, horses, donkeys, cattle, sheep and goats are kept in these regions.

Figure 1. Yak distribution in Western High Asia

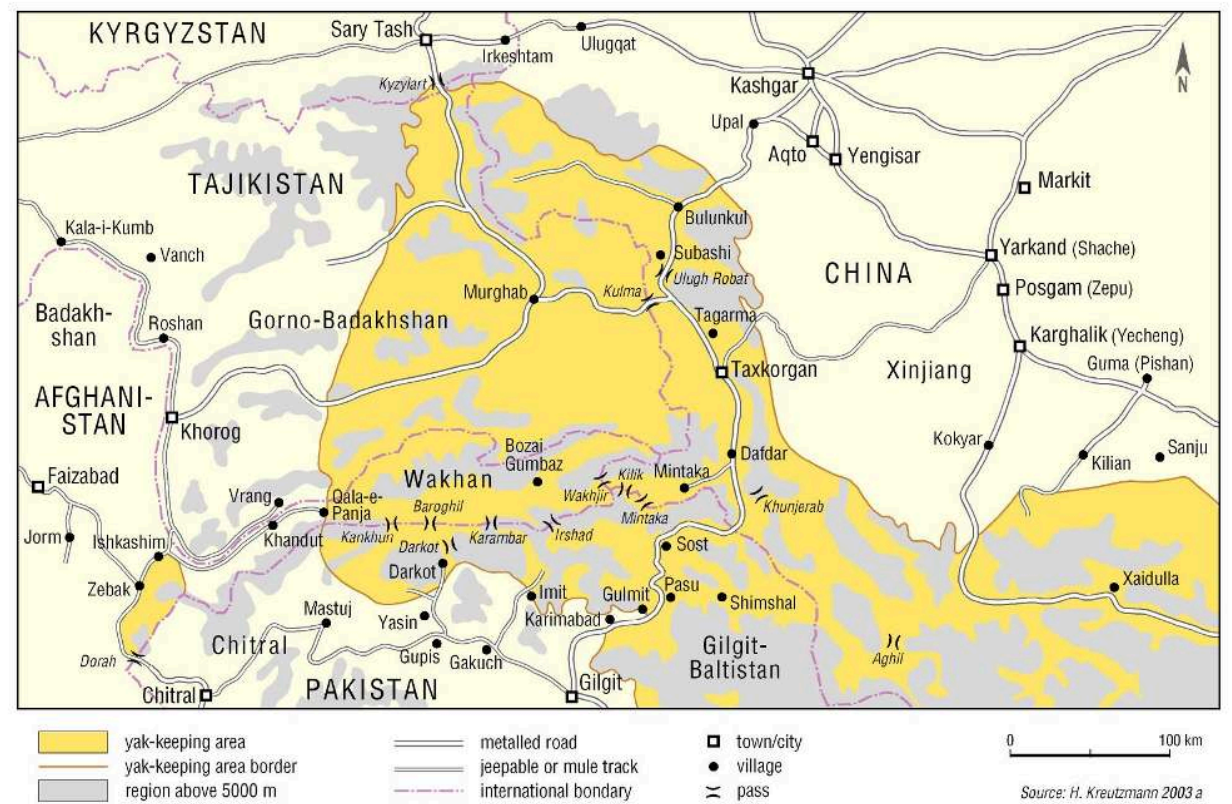

\section{Traditional pasture utilisation strategies}

What is the connotation of tradition in a present-day pastoral context? Our limitations in observation become quite obvious when we reduce the patterns of adaptive strategies to the binary pair of combined mountain agriculture and nomadism ${ }^{1}$. Nevertheless, both strategies are roots for recent developments that will be highlighted in the following. Combined mountain agriculture addresses the complementation of pastoral strategies that derive their economic potential from natural grass assets by crop and fodder cultivation. Approaches inspired by modernisation theories emphasise the linkages between supplemental fodder production and seasonal use of summer pastures. The higher mobility involved in classical nomadism is still important for the target groups of modernisation. The settlement of pastoralists has gained significant momentum in recent years.

4 1) The adaptation of combined mountain agriculture (fig. 2) has the advantage of simultaneous fodder production in the permanent homesteads for herds that are grazed in the high-lying pastures during the summers. The limiting factor here is the provision of feed for up to nine months, which has to be produced on private or common property village lands ${ }^{2}$. Livestock is kept in either location; often lactating cows and a few transport animals are kept in the homesteads. In spring or early 
summer the major livestock such as sheep, goats and yaks are transferred to the high pastures where milk is processed and where the flocks gain weight. After their return to the homesteads in late summer, fodder and crop residues are provided as principal feed in addition to scavenging on harvested fields and grassy patches within the village lands. A few animals are marketed; even fewer are slaughtered for home consumption. Livestock acts as an additional asset and as a measure of security. In times of cash needs, animals are sold to entrepreneurs or butchers. While village lands are often owned by individual households, pastures are predominantly the common property of lineages and communities.

Figure 2. Combined mountain agriculture

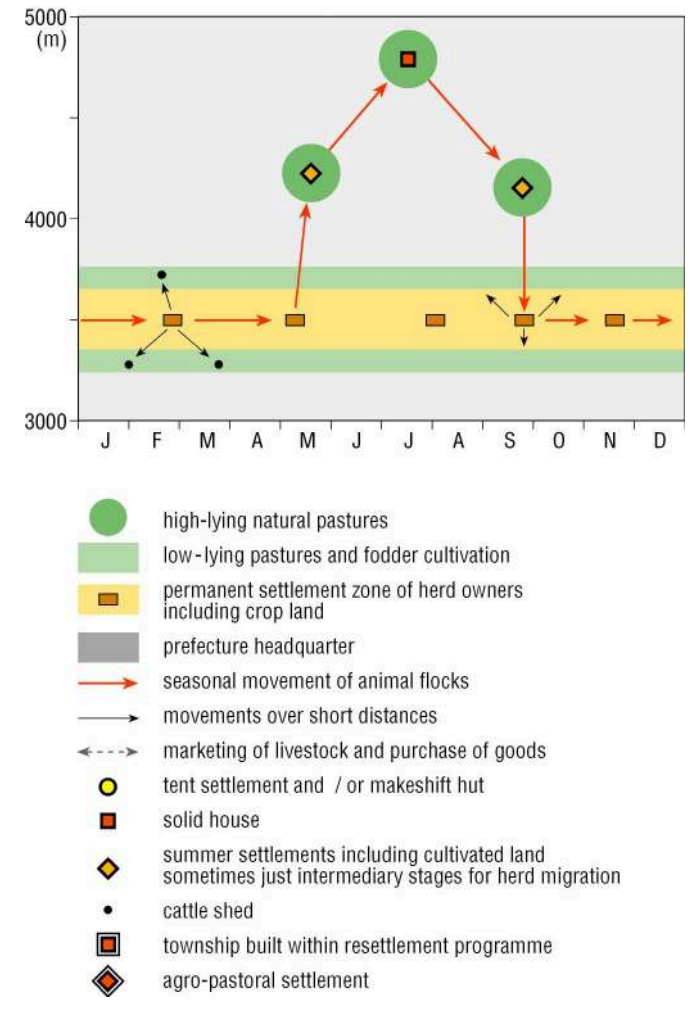

Design by Hermann Kreutzmann

2) At least traditionally, nomadic groups were able to exploit natural resources at dispersed locations. Great distances in the order of several hundreds of kilometres separated economically valuable summer mountain pastures from winter camp sites, with areas of less economic interest in between. Sometimes spring and/or autumn pastures were frequented when suitable forage was accessible. Projected on the studied region, a "classical mountain nomadism" (fig. 3) with functional migration cycles could be established in a historical context ${ }^{3}$. Here the commercially valuable flocks were much larger and fat-tailed sheep were the prime asset. Transport animals such as yaks, Bactrian camels, horses and donkeys were kept for the annual long-distance migration. Economically successful pastoralists invested in large herds from which surplus animals were marketed in autumn. In some cases specialised household or community members approached the well-established livestock markets in affluent urban settings with selected animals before rejoining the group in the winter pasture camps. Depending on favourable environmental and socio-political conditions, the leaders of 
some nomadic groups became very affluent and influential themselves. Very often the nomadic peoples were better off than their resident neighbours who were mainly engaged in crop farming and/or combined mountain agriculture ${ }^{4}$. Nevertheless, exchange systems between both groups existed as nomads were dependent for their staple food - such as wheat flour and other items - not only on bazaars but also on mountain farmers.

Figure 3. Classical mountain nomadism

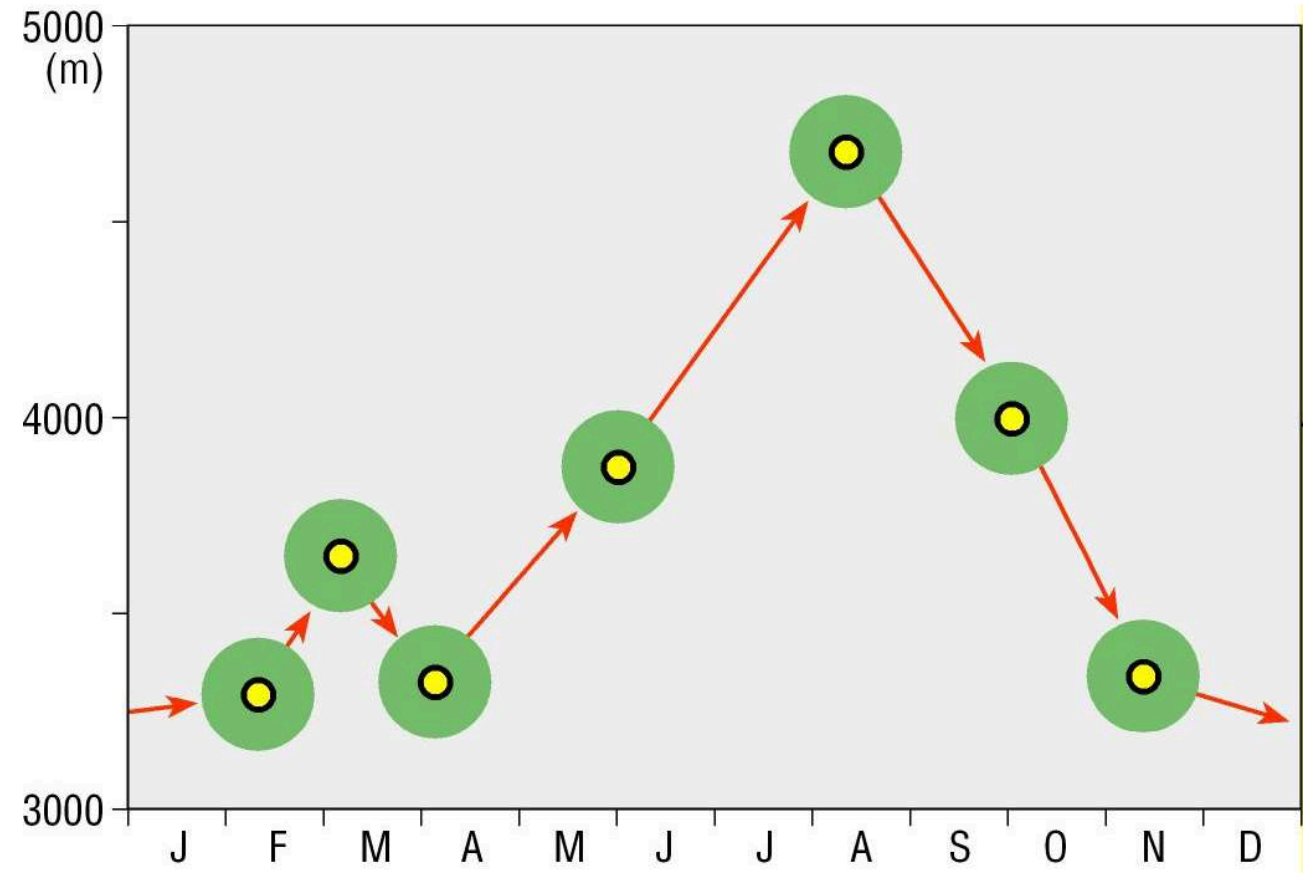

Design by Hermann Kreutzmann

3) Detached mountain pastoralism (fig. 4) is a more recent strategy reflecting societal transformations, collectivisation and forced sedentarisation and settlement in highlying grazing grounds. Basically the long-distance migrations ceased to exist and were replaced by short-distance migrations at a rather high altitude of permanent abodes, usually above $3000 \mathrm{~m}^{5}$. The former winter grazing grounds have become rural settlements with crop cultivation and their own livestock regimes. Both areas are connected by annual exchanges of goods. Livestock products are exported from the high pastures and exchanged for all kinds of necessities needed for life in the Pamirs. 


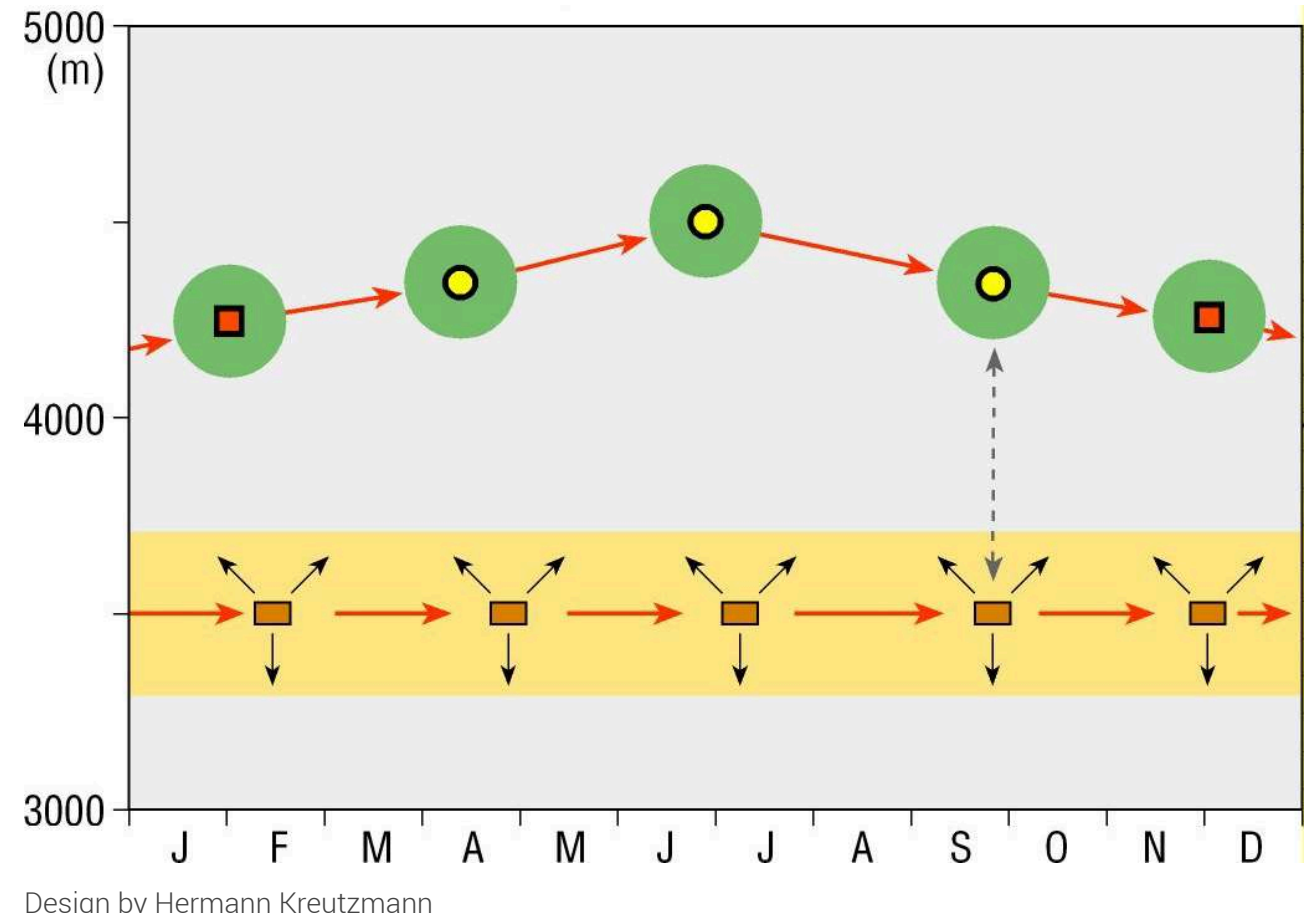

In recent years two new forms of organising pastoralists have been tested and implemented that can be regarded as a further step in "developing" and "modernising" peripheral communities and finding their visual expression in fencing pasture areas. Under the heading of "resettlement" two approaches are followed:

4) Resettlement in high pastures (fig. 5). In furthering the modernisation attempts of previous interventions in pastoral communities, schemes have been designed that bring features of urbanisation to pastures and their inhabitants. A concentration of pastoralists' habitations in newly built townships envisages economies of scale in terms of infrastructure provision, health and educational institutions, agricultural extension services, marketing of livestock products and supply of basic goods.

Township development in remote locations and enormous investment in infrastructure development are based on external subsidies that affect the livestock sector by creating fenced spaces at a hitherto unknown scale. A strong relationship between the pastoral counties and their newly built townships, on the one hand, and the cities functioning as prefecture seats, on the other, is the basis for a modern network of communication and exchange. The idea is well in tune with conventional regional planning inspired by modernisation theories, thus creating a web of settlements that is integrated into a system of central places at higher levels. 
Photo 1. Fencing as a tool for optimising pasture utilisation

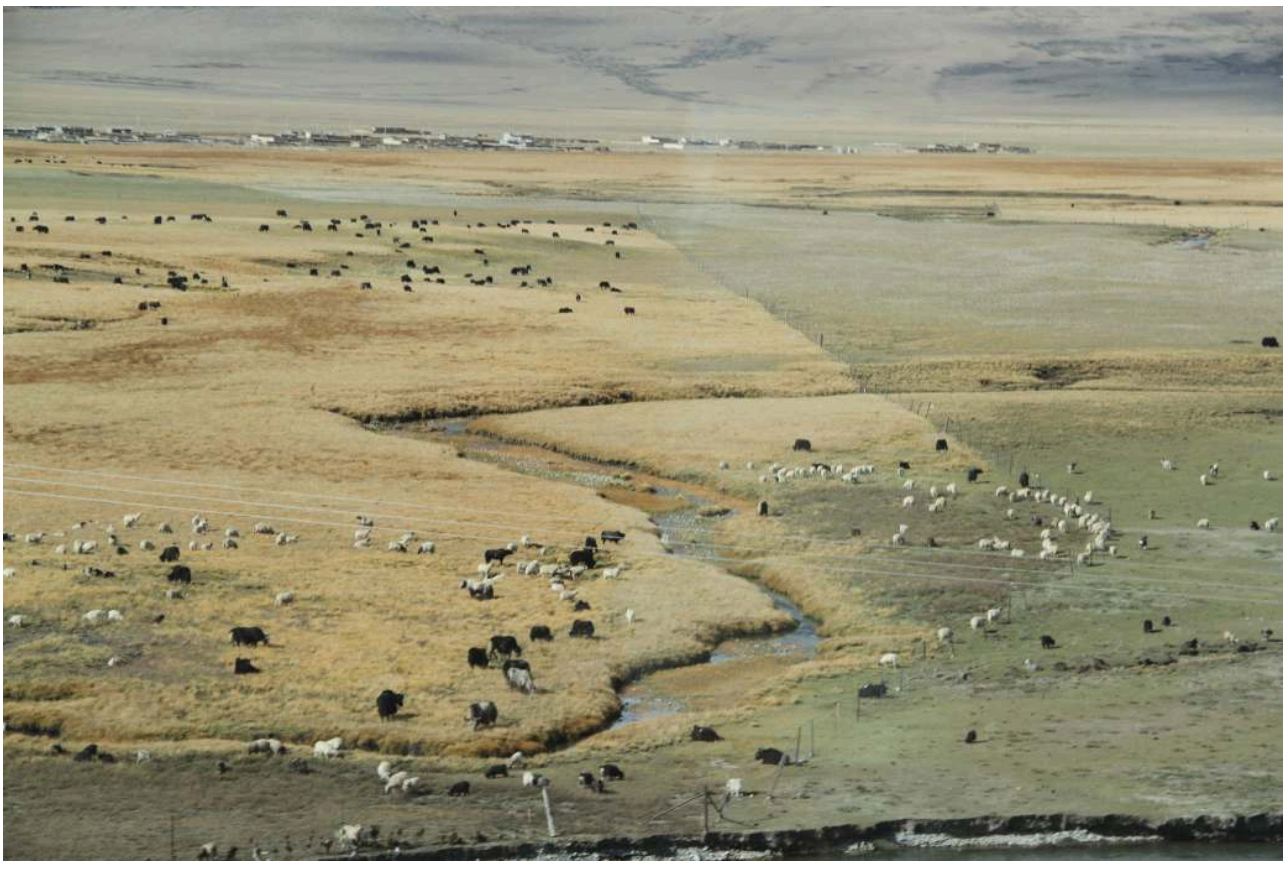

Hermann Kreutzmann (October 2010)

Figure 5. Resettlement programmes in high pastures

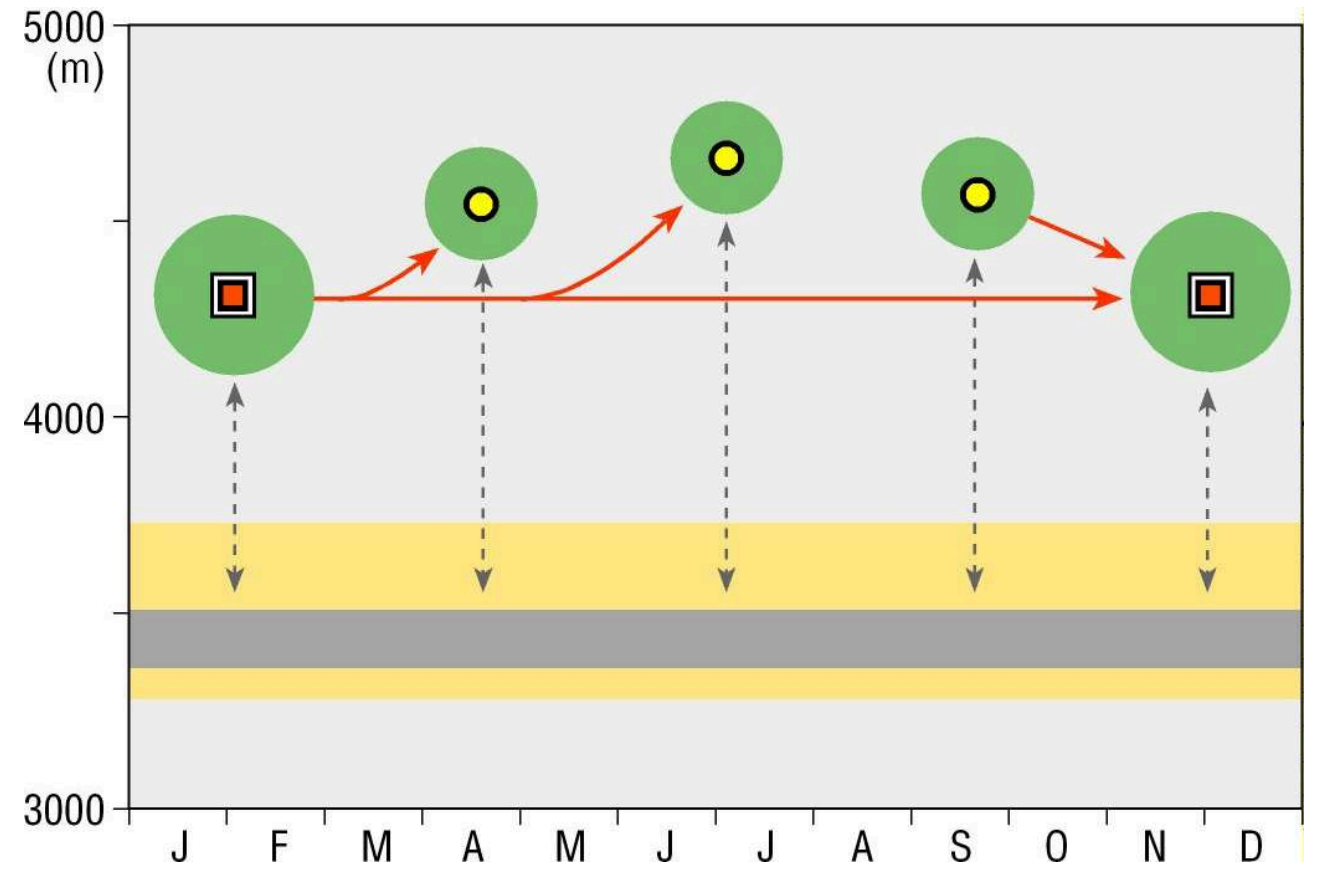

Design by Hermann Kreutzmann

5) Agro-pastoral resettlement schemes in lowland regions (fig. 6). The second approach of recent times is inspired by the notion that development does not take place in remote mountain areas. Consequently, mountain dwellers are resettled in lowland regions close to urban areas where infrastructure is available and easily accessed. The price is the relocation of pastoralists far from their summer pastures to sites close to 
the consumer markets. The greater distances to be covered need additional support for herd migration or rather herd transport on trucks to their summer pastures. Agropastoral resettlement is envisaged for those mountain areas that are located at the fringes of the Tibetan Plateau or that are close to low-lying areas where distances are manageable. For vast tracts of the Tibetan Plateau these distances to be covered are considerable and therefore less feasible ${ }^{6}$.

Figure 6. Agro-pastoral resettlement scheme in lowland regions

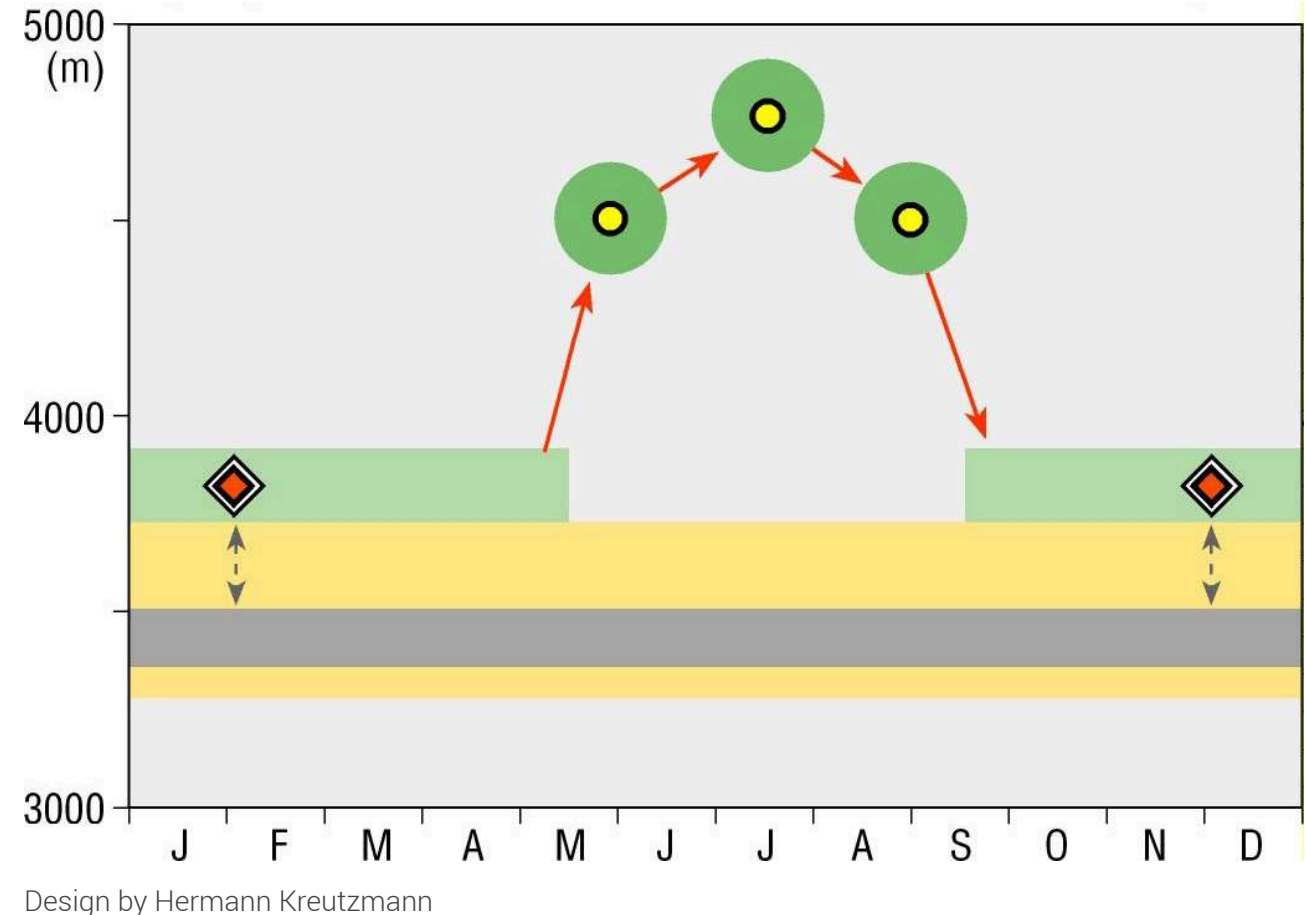

All approaches can result in competing for natural resources in the same location and have frequently been discussed from that perspective. The ecological aspect has been expanded to the debate about conflicting economic strategies. Sometimes the political dimension of power and influence, grazing taxes and the levying of them, threat and security is neglected in the historical context. In recent times we have to concentrate on the challenges between external planners and local user groups, between perceptions of modernity and preferences of lifestyles, between subsidised interventions and stakeholder participation.

11 In the discourse of modernisation and social change, nomadism's place is usurped by agriculture. In the context of development in stages, the sequential order of nomadism prior to crop farming is highlighted, although historical evidence always pinpoints the co-existence of both. Modernisation theory made it a vital argument to perceive progress as a transition from mobile economies to settled farming and entrepreneurship. The co-existence of both in Central Asian mountain regions reflects their complementarities and interdependence : nomadism/pastoralism is not feasible without exchange relations with farmers and markets. Nevertheless, the altitudinal limits of habitations and the utilisation of marginal lands have significantly shifted towards high-lying and arid areas. The extensive utilisation of marginal resources has been superseded by intensification and increasing external inputs. Consequently, it is not surprising that mountain farmers and pastoralists have been a prime target for 
"development", which aims to reduce subsistence levels by integrating people from the periphery into the mainstream of nation states, thus endangering and transforming "traditional" lifestyles and locally developed economic strategies. The example of Xinjiang will be presented as a general case, the Kara Köl setting in Kizil Su Kirghiz Autonomous Prefecture as a specific case in point.

\section{Pastoralism in Xinjiang}

In Xinjiang 1,16 million pastoralists are living in 275800 households. The natural pasture land covers 57 million hectares of which 48 million hectares are used. The Communist Party Committee and the Regional Government of Xinjiang started a "modernisation" campaign in the 1980s. By the end of 2009 more than one third of all pastoral households, 106500 households or 38,6\%, had been settled under this label. The Government institutions claimed that the winter mortality rate for livestock could be reduced from $10 \%$ in the 1990 s to $1,5 \%$. The per capita income more than doubled from 1050 Yuan in 1996 to 2490 Yuan in 2008. Animals are kept in sheds during the winter while summer pasturing continues ${ }^{7}$.

The new planning approach aims at a so-called "ecological replacement strategy" that involves significant effects for the utilisation of natural pastures and herd composition : In future 700 million mu (15 mu equal one hectare) of natural pastures will be designated as such. Of this area, 100 million mu of degraded non-summer pastures will be excluded from animal husbandry for a period of up to ten years. The basis for pastoralism is an area of 450 million mu on which reduced and rotational grazing will be allowed and where fencing will spread over the entire traditional grazing land. To complement the fodder demand, 10 million $\mathrm{mu}$ of irrigated fields for fodder cultivation will be established in addition to 20 million $\mathrm{mu}$ of grass fodder production including 10 million $\mathrm{mu}$ of reserve land in crop farming areas ${ }^{8}$. Consequently, 40 million sheep will be shifted from traditional pasture areas to irrigated oases, and 30 million sheep will be kept during the cold season in newly designed sheds with stall-feeding. Two outcomes are expected: the restoration of degraded pastures and an improvement of the local economy.

In 2009, the Goverment allocated 300 million Yuan for the construction of pastoralists' settlements including central animal sheds in Xinjiang as part of the "Implementation Plan of the Xinjiang Pastoralists Sedentarization Program" (Zhao Xinchun 2011). The overall goal of this campaign is the settlement of pastoralists in townships that are supposed to provide urban amenities, to concentrate animals in centralised animal sheds during the winter period, to transport herds on trucks to their summer pastures, to cultivate highly nutritional fodder in irrigated oases and to create a new division of labour. Fewer pastoralists are expected to perform a more efficient animal husbandry, while the surplus labour force is expected to be employed in non-agrarian jobs. The justification for these measures comes under the disguise of environmental protection ${ }^{9}$ and modernisation. 


\section{Kirghiz pastoralists in Kizil Su - Exposure to another transformation}

The relationship between silk Route oases and fertile pastures in the vicinity of glaciated mountains has a long tradition. Fat-tailed sheep have always been precious trading objects that were fattened on the green pastures during summers and were driven to livestock markets in urban oases where fodder was plentiful and available on harvested irrigated fields ${ }^{10}$. The oases are mainly located in the interface between mountain and desert, while the summer pastures are to be found in the Tian Shan, Pamirs and Kun Lun Shan. Yaks and other livestock were kept for transport and the maintenance of the pastoral communities. The Kirghiz of Kizil Su are a prime example of "classical mountain nomadism" (cf. fig. 3) as reported by Sven Hedin (1899). They followed a long-distance nomadic migration cycle between the summer grazing grounds in the Pamirs and the irrigated oases of the mountain forelands. Kirghiz nomads spent the winter occupied with herding and various other businesses in the towns of Kashgar and Yarkand. The usual pattern has been principally and significantly abridged within the last 60 years and especially during the last generation of pastoralists (Figure 7) ${ }^{11}$. Nowadays the Kirghiz pastoralists remain confined to the Pamir regions with their herds all year round. Only for marketing purposes do they leave their mountain abodes and travel on foot with their flocks or on rack body trucks down to the Sunday markets of Kashgar and/or Yarkand. Thus, the herds cover the distance of $280 \mathrm{~km}$ easily and without great loss of weight.

Photo 2. The new resettlement scheme in Bulunkul

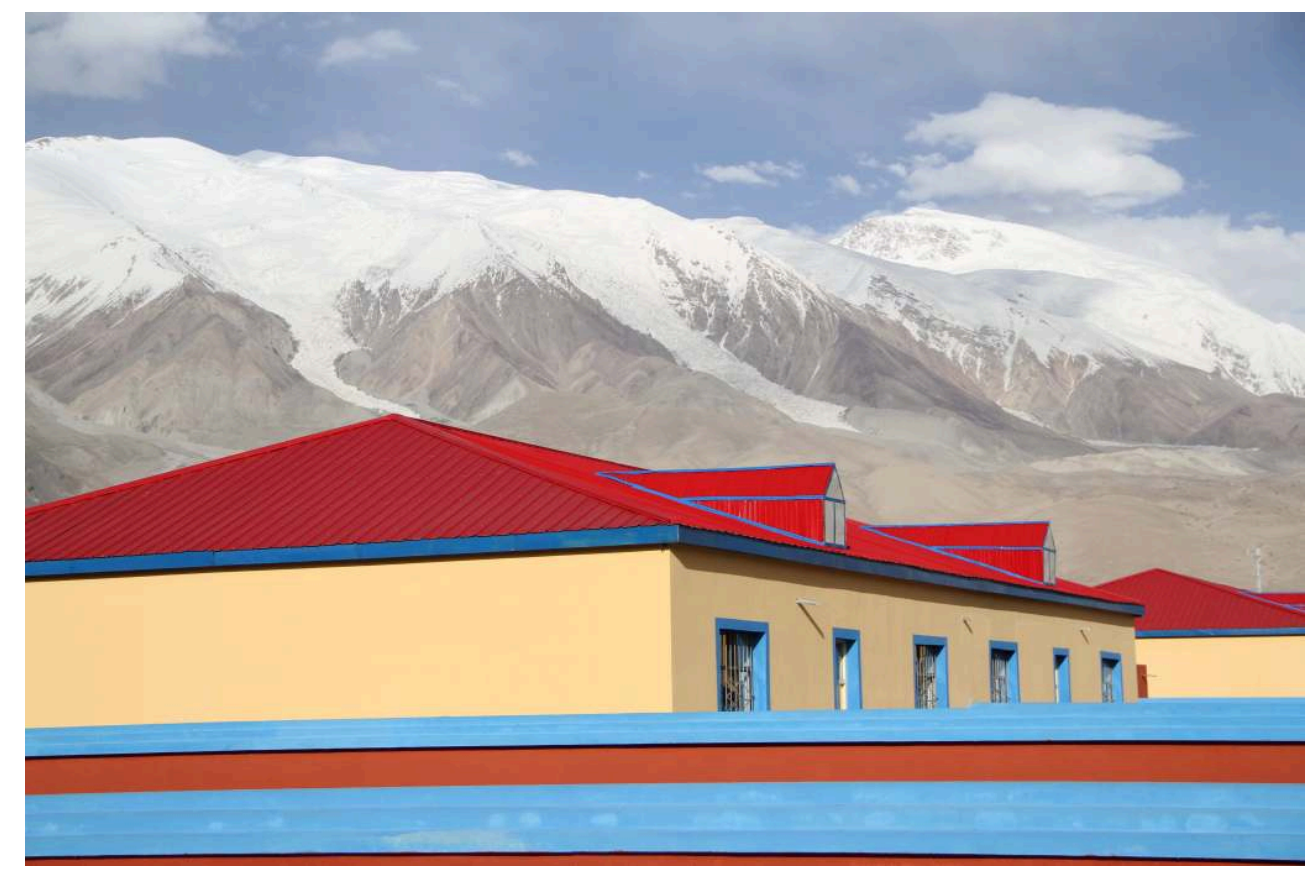

Hermann Kreutzmann (2009) 
Figure 7. Recent transformations in pastoral strategies in Little Kara Köl Pamir
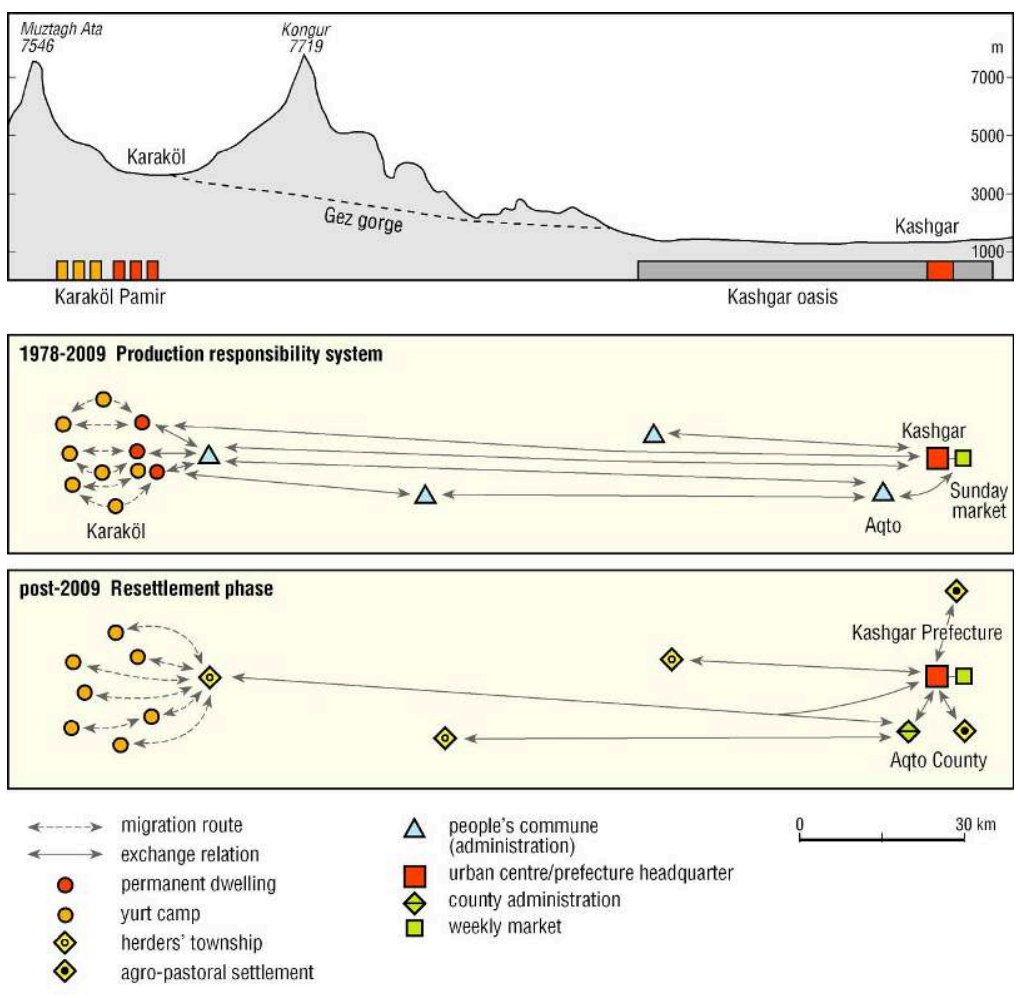

Design by Hermann Kreutzmann

16 The pasture system has been adjusted to changed frame conditions. Along with grave changes in the social organisation and production strategies, the livestock numbers increased from 10300 in 1976 to more than 30000 in 1991. Since then they have continued to grow ${ }^{12}$. Besides rising livestock numbers "classical mountain nomadism" came to an end when the structural reforms in post-revolutionary China created production brigades and people's communes by 1958 . This move was probably the most severe in terms of victims and changing lifestyles. Kirghiz pastoralists were compelled to live permanently in the Little Kara Köl. The headquarters of the production brigade at Subashi $(3600 \mathrm{~m})$ is equipped with familiar infrastructure institutions and with a veterinary post controlling the quality and health status of animals. The livestock and its products were delivered to the livestock department at the county headquarters in Aqto (cf. fig. 7). In return all necessities for life in the pasture settlements were provided at nominal cost. Though very restricted in their movements and decisionmaking, the Kirghiz secured their basic livelihoods and their living conditions improved. Despite harsh environmental conditions of survival the animals raised in these productive pastures are high-quality products. 
Photo 3. The settlement of Subashi as the production brigade's centre for infrastructural assets

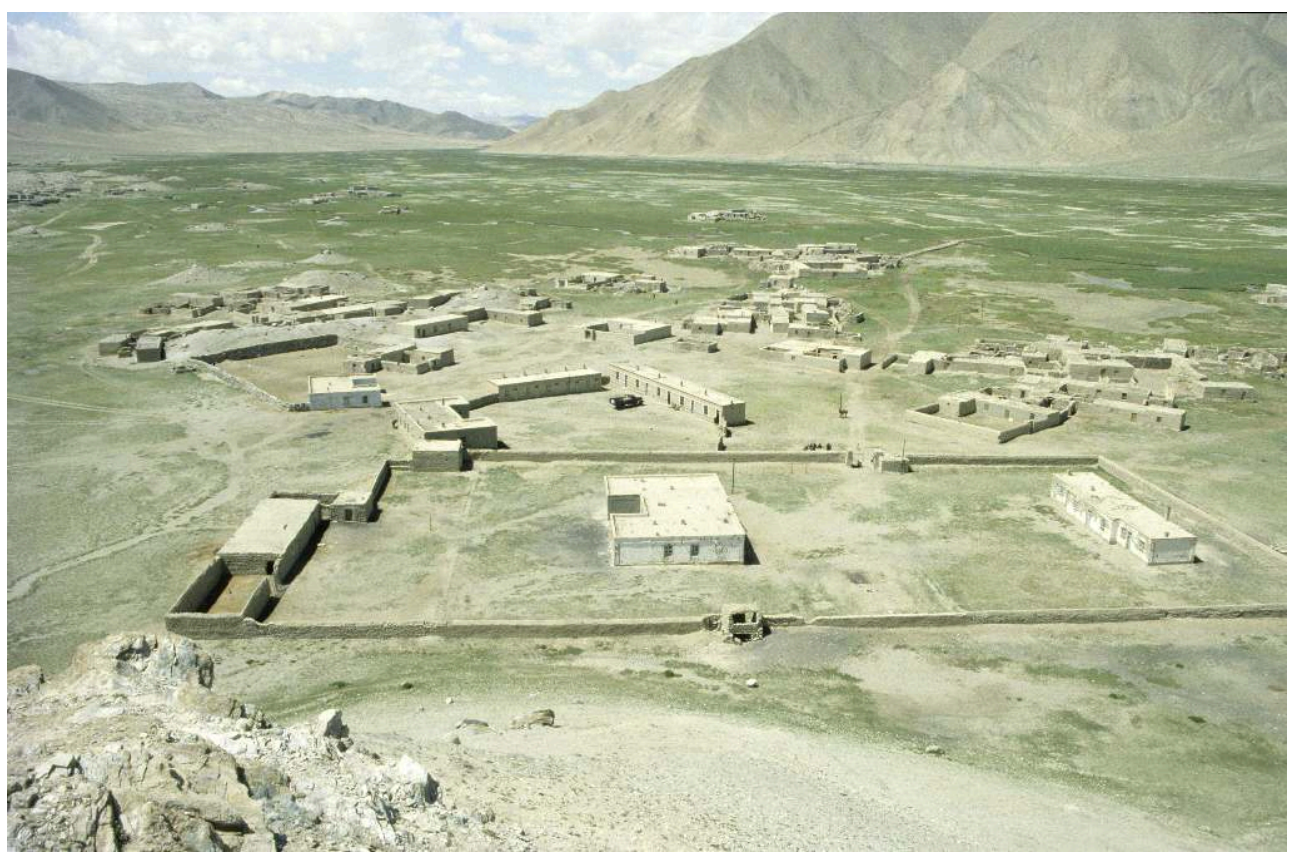

Hermann Kreutzmann (1990)

The value of the niche production in the Pamirs reached its peak when after 1978 the "production responsibility system" (cf. fig. 7) was introduced and the Kirghiz gained greater degrees of freedom and leverage power in their own economic activities and marketing. Their livestock compete very well on the profitable markets in the urban oases along the southern silk route (Tarim basin). Today the Kirghiz are respected as one of the most affluent livestock-breeding communities of the region. Within a few years they have re-established profitable market relations with the Sunday market in Kashgar where affluent buyers purchase their fat-tailed sheep at high prices. In socioeconomic terms the Kirghiz of Little Kara Köl fare best among their relatives and neighbours ${ }^{13}$.

Nevertheless, development and modernisation never stops. In a major move to improve the living conditions in remote locations, including mountain regions, the central planning institutions have developed so-called "resettlement schemes", concentrating infrastructural assets, social amenities, veterinary services and marketing facilities. The rationale provided is, first, the application of economies of scale in the periphery and, second, nature protection by concentrating settlement space and facilities for animal husbandry and fodder production. From 1954 to 2008 the number of livestock in Kizil Su Autonomous Prefecture increased by a factor of 2,8 to approx. 1,6 million heads. In the case of Little Kara Köl Pamir the latest strategy has been implemented since 2009 when a new township by the name of Bulunkul was founded. The township aims at providing housing and social infrastructure for all herders' households that are presently scattered in the area of the former people's commune Bulunkul. During the first phase, 450 out of 1600 households will be resettled in housing schemes that are supported by federal and regional funds as well as by rich cities such as Shanghai ${ }^{14}(c f$. fig. 7).

19 Traditional pastoralism cannot give herders the "pleasures of modernization" as Zhao Xinchun phrased it in his presentation during an international conference in Kashgar 
2010. Moving herders to the foot of the mountains - to agro-pastoral settlements - or to resettlement townships within the mountains - as in the case of Bulunkul - are strategies aiming to provide pastoralists with amenities that allow them "to live in a stable manner and to get rich" (ibid.). Infrastructure assets incorporate "three accesses: water, electricity and roads; four availabilities: herders' houses, animal sheds, fodder and silage ; five support schemes : schools, cultural centres, clinics, shops, technical service stations" (ibid.). Since 2000 the pace of resettlement has been enhanced and a re-planning of the function of natural pastures has been undertaken. In this framework Little Kara Köl Pamir has been identified as one of the resettlement schemes that are regarded as "the biggest livelihood projects in Xinjiang". The ultimate path leads to a transformation of livelihoods that incorporates the "resettlement of herders as labourers in other areas. The remaining herders can engage in pastoralism and economies of scale, increase the market supply and thus increase the pastoralists' income leading to a modernisation of mountain pastures and the modernisation of pastoralism. Voluntary participation of herders in resettlement programmes is based on hearings at township level, annual sessions of party committees. Wishes can be articulated through proper channels" (ibid.). ${ }^{15}$ It will be seen in the near future how the lifestyle, economic position and social organisation of Kirghiz herders may have been changed. The Xinjiang example seems to be in tune with the Tibetan experience that commenced with similar modernisation strategies since the 1980 s.

\section{Recent changes in Tibetan pastoral contexts}

Tibet and pastoralism seem to be interchangeable. The vast tracts of the Changtang offer remote and widespread spaces for pastoral activities : "Tibet is reputed one of the five largest pastoral areas in China. It has 82,07 million ha of natural alpine rangeland, representing $21 \%$ of the total natural rangeland of the nation and $68,1 \%$ of the total land area of Tibet" (Long Rui Jun et al. 2011).

21 Significant change to rural areas and pastoral communities was brought about when after 1978 Deng Xiaopeng's "four modernizations" were implemented by "reform and opening-up" (gaige kaifang) strategies. The introduction of the "household responsibility system" and the dissolution of the peoples' communes started the process of de-collectivisation. Since three decades some observers have noted a revival of a "nomadic way of life" 16 ; others perceive the distribution of communal livestock among households and the contracting of grassland user rights to them as the beginning of a deregulation and privatisation in the pastoral sector ${ }^{17}$. For nearly two decades this strategy was the conventional approach in giving certain degrees of freedom to pastoralists.

In recent years the planning vacuum seems to have been filled again. With the "Fourway scheme" (sipeitao jianshe) an attempt to improve infrastructure and to provide necessary public services was introduced that specifically affected living and production in the grassland areas. Four key "constructions" were identified that aimed at significant changes in the livelihood conditions : First, based on current experiences with appropriate construction techniques, an attempt to introduce "modern" housing and suitable livestock shelters is being implemented with significant external subsidies. Second, in order to optimise pasture utilisation, fencing of pastures has been identified as an efficient tool to rationalise animal husbandry. Third, social infrastructure based 
on schools and health facilities is to be made available to pastoralists. Fourth, pasture user rights are contracted to pastoral households on a private ownership basis. This strategy was started before the turn of the millennium when the "Great Development of the West" campaign was initiated, into which the "four constructions" fitted well. Shortly afterwards, a new turn and modification of planning came up that has been characteristic for the past decade and that might give directions for the future.

\section{Resettlement programmes}

The observation stated above - that significant proportions of pastures on the Tibetan Plateau and in adjacent regions such as Xinjiang are severely degraded - has supported the introduction of further measures that have been justified on ecological and economic grounds ${ }^{18}$. The "restore pastures to grass" (tuimu huancao) campaign as part of the wider framework of "farmland to forest" (tuigeng huanlin) is accompanied by slogans such as "grain to green" and aims at poverty reduction in a comprehensive policy approach. "Poverty alleviation through migration" (yimin fupin) suggests a new dynamic involving the people to be moved. Resettlement schemes as they have been introduced since 2002 aim at population concentration in "resettlement in high pastures" or "agro-pastoral resettlement in lowland regions" (cf. fig. 5 \& 6). In either case concentrated settlements resembling townships are envisaged that will provide all infrastructural assets for a decent life. Animal husbandry will significantly change as fewer shepherds will be involved in schemes that concentrate livestock in central stables/shelters and that provide sophisticated livestock-specific agricultural extension and veterinary care. The rationalisation of livestock-breeding and pasture utilisation sets free a workforce that is meant to become migrant workers and labourers in cities. During the last five years these strategies have become more specific: "ecological migration" (shengtai yimin) addresses both objectives. First, environmental protection is supposed to be enhanced by out-migration of pastoralists and abandonment of previously regularly used pastures. The aim is to preserve biological diversity and water sources by reducing overgrazing and environmental degradation by "depopulating the Tibetan Grasslands" ${ }^{19}$. The second objective supports "modernisation" of lifestyles by providing urban amenities in new forms of settlements that fulfil the size requirements and are well connected to central places of higher order, thus enabling a flexible approach and exchange. Sedentarisation seems to be the strategy of the hour, aimed at nearly all pastoralists of the Tibetan steppe. Little choice remains for alternative lifestyles and production strategies when resettlement is the only adaptive strategy implemented that deals with challenges of climate, global and social change.

\section{Future prospects for pastoral practices - some conclusions}

Environmental protection and the ambition to bring modernity to the remote corners of High Asia are the driving forces for the most significant intervention in pastoral systems since collectivisation. Presently only a few alternatives and other remedies are discussed in order to cope with pasture degradation. The notion of pastoralism as a sustainable practice seems to fade in favour of modernity. An option presently 
discussed in China as well could be the payment for ecosystem services, a strategy ${ }^{20}$ in which the pastoralists are remunerated for their function as landscape managers. Payment for ecological services involves the reduction of flocks to an acceptable herd size that allows sustainable management of pasture resources. The difference between present high stocking quotas and acceptable ones would be paid in cash to the herdsmen by government authorities. In pilot projects the payment amounts to about a third of the pastoralists' household income ${ }^{21}$. In view of the huge amounts of government investments that are planned to be allocated for resettlement schemes, it could be a worthwhile consideration to evaluate the advantages of having pastoralists as active landscape managers instead of removing them in great style from pastures that have been used for centuries. The indigenous knowledge accumulated by pastoralists over many generations seems too valuable to just be neglected or omitted ${ }^{22}$.

The modernisation approach seems to be an even stronger argument than the environmental rationale. The aim of the chinese authorities to let pastoralists participate in modern lifestyles is embedded in twinning programmes in which affluent coastal cities are supposed to pay for the development of backward regions through modernisation programmes as described above. Projected on the Tibetan Plateau, the question remains whether there is only one way forward. Critics of the resettlement schemes suggest that in contrast to the top-down approach a "community-comanagement" 23 could be helpful by incorporating local stakeholders, the pastoral households as local communities, as equal partners in a joint effort to design development packages that are accepted by all. Thus, valuable indigenous knowledge that regional planners nearly always lack could be made useful for tackling a complex constellation that calls for holistic and sensitive approaches. In any case, a decisionmaking process based on consensus supports acceptance, participation and understanding. For the future of the pastures on the Tibetan Plateau, in Xinjiang and in adjacent mountain regions this could be an exemplary model for reducing regional disparities.

Barfield, T.

1993 The Nomadic Alternative (Englewoods Cliffs, Prentice Hall), 230 p.

Brower, B. \& Johnston, B. R. (eds.)

2007 Disappearing peoples? Indigenous Groups and Ethnic Minorities in South and Central Asia (Walnut Creek, Left Coast Press), $275 \mathrm{p}$.

De Groot, R. S., Wilson, M. A., Bouman, R. M. J.

2002 A typology for the classification, description and valuation of ecosystem services, goods and services, Ecological Economics 41, pp. 393-408.

Ehlers, E. \& Kreutzmann, H.

2000 High mountain ecology and economy. Potential and constraints, in E. Ehlers \& H. Kreutzmann (eds.), High Mountain Pastoralism in Northern Pakistan (Stuttgart, Steiner), pp. 9-36.

Felmy, S. \& Kreutzmann, H.

2004 Wakhan Woluswali in Badakhshan. Observations and reflections from Afghanistan's periphery, Erdkunde 58(2), pp. 97-117.

31 Foggin, M. J.

2008 Depopulating the Tibetan Grasslands. National Policies and Perspectives for the 
Future of Tibetan Herders in Qinghai Province, China, Mountain Research and Development 28(1), pp. 26-31.

Goldstein, M. \& Beall, C.

1991 Change and Continuity in Nomadic Pastoralism on the Western Tibetan Plateau, Nomadic Peoples 28, pp. 105-22.

Hedin, S.

1899 Durch Asiens Wüsten. Drei Jahre auf neuen Wegen in Pamir, Lop-Nor, Tibet und China (2 Vols.) (Leipzig, Brockhaus), 236 \& 243p.

34 Ho, P.

2000 The clash over state and collective property: The making of the rangeland law, China Quarterly 16(1), pp. 240-263.

2001 Rangeland degradation in China revisited ?, Journal of Development Studies 37(3), pp. 99-132.

35 Humphrey, C. \& Sneath, D.

1999 The End of Nomadism? Society, State and the Environment in Inner Asia (Durham, Duke University Press), 355p.

36 Jest, C.

1975 Dolpo. Communautés des langue tibétaine du Nepal (Paris, Éd. du CNRS), 482p.

37 Khazanov, A. M.

2005 Nomads and cities in the Eurasian Steppe region and adjacent countries: A historical overview, in S. Leder and B. Streck (eds.), Shifts and drifts in nomad-sedentary relations (Wiesbaden, Reichert), pp. 163-178.

Khazanov, A. \& Wink, A.

2001 Nomads in the sedentary world (London, Curzon), 297p.

39 Kreutzmann, $\mathrm{H}$.

1995 Mobile Viehwirtschaft der Kirgisen am Kara Köl. Wandlungsprozesse an der Höhengrenze der Ökumene im Ostpamir und im westlichen Kun Lun Shan, Petermanns Geographische Mitteilungen 139(3), pp. 159-178.

2005 Pastoral practices and their transformation in the North-Western Karakoram, Nomadic Peoples 8(2), pp. 54-88.

2009 Transformations of High Mountain pastoral strategies in the Pamirian Knot, Nomadic Peoples 13(2), pp. 102-123.

Long Rui Jun, Liu Xingyuan, Cui Guangxin \& Zhang Weimin

2011 Socio-economic changes in pastoral systems on the Tibetan Plateau, in $\mathrm{H}$. Kreutzmann, N. Tashi \& J. Richter (eds.), Regional Workshop in Lhasa 2010 - Pastoralism and Rangeland Management on the Tibetan Plateau in the context of Climate and Global Change (Bonn, InWEnt) (in print).

41 Manderscheid, A.

2001 Decline and Re-emergence of Nomadism : Tibetan Pastoralists Revive a Nomadic Way of Life and Production, GeoJournal 53, pp.173-82 (http://www.cwru.edu/affil/ tibet/booksAndPapers/Decline \& Re-emergence of Nomadism.htm).

42 Miller, D.

2000 Tough Times for Tibetan Nomads in Western China : Snowstorms, Settling down, Fences, and the Demise of Traditional Nomadic Pastoralism, Nomadic Peoples 4(1), pp. 83-109. 
2002 The Importance of China's Nomads. The sustainable future development of China's rangelands depends on integrating nomads' indigenous knowledge, in Rangelands 24(1), pp. 22-24.

Montero, R. G., Mathieu, J. \& Singh, C. 2009 Mountain pastoralism 1500-2000. An introduction, Nomadic Peoples 13(2), pp. 1-16.

\section{Oi, J. C.}

1999 Two decades of rural reform in China : an overview and assessment, The China Quarterly 159, pp. 616-628.

\section{Qu Hua}

2009 Poverty alleviation in Xinjiang's mountain areas, in H. Kreutzmann et al. (eds.), Integrated Tourism Concepts to Contribute to Sustainable Development in Mountain Regions (Feldafing, InWEnt), pp. 140-146.

\section{Salzman, P. C.}

2004 Pastoralists. Equality, Hierarchy and the State (Boulder, Westview), 193p.

Samimi, C., Vanselow, K., Kraudzun, T. \& Kreutzmann, H.

2009 Ecosystem Services in the Eastern Pamirs of Tajikistan. Can a price be ascertained ?, in Mountain Forum Library (http://www.mtnforum.org/rs/ol/browse.cfm? $\mathrm{tp}=\mathrm{vd} \&$ docid $=5443$, accessed 14 January 2011)

Schlee, $G$.

2005 Forms of Pastoralism, in Shifts and Drifts in Nomad-Sedentary relations, in S. Leder and B. Streck (eds.), Shifts and drifts in nomad-sedentary relations (Wiesbaden, Reichert), pp. 17-53.

Scholz, F.

2008 Nomadism. A Socioecological Mode of Culture (Ulaanbaatar, International Institute for the Study of Nomadic Civilizations), $235 \mathrm{p}$.

Shahrani, M. N.

1979 The Kirghiz and Wakhi of Afghanistan. Adaptation to Closed Frontiers (Seattle and London, University of Washington Press ; reprint 2002), $264 \mathrm{p}$.

1 Sha-Zhou An, Jian Dai, Zhaohui Lu, Yonggang Meng \& Xiao-Yuan Liu

2011 Pastoralism in China's Xinjiang Kizilsu Kirghiz Autonomous Prefecture, in H. Kreutzmann, Abdulalishoev, K., Lu Zhaohui and J. Richter (eds.), Regional Workshop in Khorog and Kashgar. Pastoralism and Rangeland Management in Mountain Areas in the Context of Climate and Global Change (Bonn, InWEnt) (in print).

Sheehy, D. P., Miller, D. \& Johnson, D. A.

2006 Transformation of traditional pastoral livestock systems on the Tibetan steppe, Sécheresse 17(1-2), pp. 142-51.

53 Stevens, S. F.

1993 Claiming the high ground. Sherpas, subsistence, and environmental change in the highest Himalayas (Berkeley, University of California Press), 537p.

4 Tapper, $\mathrm{R}$.

2008 Who are the Kuchi? Nomad self-identities in Afghanistan, Journal of the Royal Anthropological Institute 14, pp. 97-116.

Wilkes, A., Jingzheng Tan, Mandula

2010 The myth of community and sustainable grassland management in China, Frontiers of Earth Science in China 4(1), pp. 59-66. 


\section{NOTES}

1. Cf. Ehlers \& Kreutzmann 2000. For a wider debate on classifications and interpretation of nomadism and pastoralism $c f$. Barfield 1993, Humphrey \& Sneath 1999, Khazanov 2005, Khazanov \& Wink 2001, Salzman 2004, Schlee 2005, Scholz 2008, Tapper 2008.

2. Combined mountain agriculture is to be found in all locations in arid High Asia where irrigated mountain oases complement the fodder base from natural high-lying pastures, e.g. in the Hindukush, Pamirs, Karakoram, Himalaya. Cf. for examples Jest 1975, Stevens 1993, Ehlers \& Kreutzmann 2000, Montero, Mathieu \& Singh 2009.

3. Well-documented examples for this are the oasis towns of the Ferghana Valley (Khujand, Koqand, Andijan, Osh), Alteshahr (six towns) at the fringes of the Takla Makan Shamo (Keriya, Khotan, Yarkand, Kashgar, Aksu and Kucha), and further examples ; cf. Brower \& Johnston 2007, Felmy \& Kreutzmann 2004, Hedin 1899, Khazanov 2005, Kreutzmann 2004, 2009, Salzman 2004.

4. A classical example for the difference in wealth are the Kirghiz and Wakhi of the Wakhan in north-eastern Afghanistan ; cf. Shahrani 1979, Kreutzmann 2009.

5. Wherever sedentarisation took place in the context of communist revolutions as part of their agenda of modernising mountain pastoralists, the efforts resulted in permanently settling mobile people at certain locations. In the case of Kirghiz nomads, examples have been studied in the Eastern Pamirs and the Western Kun Lun Shan mountains (see below); ample evidence is available from transformation processes in Kazakhstan and Kyrgyzstan. On a more general count, the changing urban landscapes in oasis towns - where animal husbandry expanded as part of a collective farm system - contributed to this form of delinking inherited practices and resulted in detached pastoralism.

6. In Xinjiang Uigur Autonomous Region examples exist that are termed agro-pastoral resettlement schemes, e.g. in Aqto County close to Kashgar. In fact, these new schemes come 
close to migration cycles in the pastwhen the Kashgar oasis was the winter abode of choice for Pamirian pastoralists. The present scheme is embedded in a quite different socio-political context and involves subsidies and support from the central state authorities.

7. All information is based on data provided by the Animal Husbandry Department of Xinjiang Uighur Autonomous Region 2009 and quoted in Zhao Xinchun 2011 (in print).

8. All information is based on data provided by the Animal Husbandry Department of Xinjiang Uighur Autonomous Region 2003 and quoted in Zhao Xinchun 2011 (in print).

9. Degradation of natural resources is perceived as a global phenomenon with grave implications for China's periphery: "Land reclamation and overgrazing are major causes for decrease of rangeland's carbon storage capacity. By 1998, over 660 million ha of rangelands have been converted to farming lands worldwide by human beings, resulting in a decrease of 19 billion metric tons of carbon storage capacity. Between 1850 and 1980, the earth has lost about 10 billion metric tons of carbon storage capacity due to rangeland conversion. In China, 19,3 million ha of rangelands have been reclaimed for agriculture between 1949 and 1999 causing a loss of $30 \%-50 \%$ of soil carbon" (Yi Shaoliang \& Ismail Muhammad 2011).

10. Well-documented examples for this are the oasis towns of the Ferghana Valley (Khujand, Koqand, Andijan, Osh) and Alteshahr (six towns) at the fringes of the Takla Makan Shamo (Keriya, Khotan, Yarkand, Kashgar, Aksu and Kucha) ; cf. Khazanov 2005, Kreutzmann 1995.

11. Studies from different periods recorded the state of affairs in the Pamirian pastures and its regional context, with some focus especially on developments in the Kara Köl region, $c f$. Hedin 1899, Kreutzmann 1995, 2009, Sha-Zhou An et al. 2011, Qu Hua 2009.

12. Kizil Su supplies less than three percent of Xinjiang's meat production and even less in terms of milk products. Nevertheless, it offers 3,5 million hectares of natural pastures, from which an estimated 2,17 million tons of fresh fodder are foraged and harvested. Chinese authorities have calculated the annual capacity for raising livestock at approx. 1,5 million sheep units (Sha-Zhou An et al. 2011).

13. Cf. Brower \& Johnston 2007, Felmy \& Kreutzmann 2004, Samimi et al. 2009.

14. The city administration of Shanghai provides the funds for this "twinning" programme, in which the state organises support schemes for "backward" regions that are financed by "rich" and "developing" regions such as the coastal cities (recorded during fieldwork in 2010 on site in Bulunkul from interviews with the project directors).

15. The quotations were recorded from the English simultaneous translation of the presentation by Zhao Xinchun, Deputy Director and Chief Scientist of Animal Husbandry, during the Regional Workshop in Kashgar on July 20, 2010 (cf. Zhao Xinchun 2011).

16. Manderscheid 2001.

17. Goldstein \& Beall 1999, Ho, 2000, Oi 1999, Yan Zhaoli et al. 2005.

18. Cf. Foggin 2008, Ho 2001, Miller 2000, Sheehy, Miller \& Johnson 2006, Yeh 2005.

19. Foggin 2008.

20. Cf. for the general discussion de Groot et al. 2002, for the China context Wilkes et al. 2010.

21. Wilkes et al. 2010, pp. 64-65.

22. Miller (2002) strongly advocates the incorporation of pastoralists' indigenous knowledge that otherwise would be lost.

23. Foggin 2008, p. 31. 


\section{RÉSUMÉS}

La Haute-Asie a vécu de nombreuses transformations au sein de la société ces dernières années ; celles-ci ont eu des répercutions importantes sur les moyens de subsistance des habitants exerçant l'activité combinée de pasteurs et de fermiers des montagnes. Il y a eu tout d'abord des changements au niveau de l'organisation de la pratique ainsi que dans les relations entre les institutions officielles et les pasteurs des montagnes. En y regardant de plus près, on constate que des changements importants prédominent dans toutes les régions concernées. Dans le contexte de la République de Chine, des cas au Tibet et au Xinjiang ont été choisis afin d'illustrer les effets des plus récents projets de délocalisation, donnant ainsi une justification pour la protection de l'environnement et la modernisation devant servir à enfreindre à la dégradation et contribuer au soulagement de la pauvreté des pasteurs des montagnes. Après la collectivisation, il s'agit là des interventions les plus effectives au sein du secteur pastoral; celles-ci vont transformer de manière signifiante l'élevage des animaux et les moyens de subsistance des pasteurs vivant en Haute-Asie.

High Asia has experienced a number of societal transformations in recent years that have significantly affected the livelihoods of pastoralists and combined mountain farmers. In the first place, changes have occurred in the management practices and the relationship between state institutions and pastoralists. A closer look reveals that significant transformations prevail in all locations concerned. In the context of the PR of China, cases from Tibet and Xinjiang are presented in order to highlight the effects of most recent resettlement schemes that follow a rationale of environmental protection and modernisation in order to stop degradation and to contribute to poverty alleviation among pastoralists. After collectivisation these are the most effective interventions in the pastoral sector and will significantly change animal husbandry and pastoral livelihoods in High Asia.

\section{INDEX}

Index géographique : Afghanistan, Kirghiztan, Tadjikistan, Chine, Tibet

Keywords : pastoralism, herding, pastoral practices, modernisation, resettlement

Mots-clés : pastoralisme, élevage, pratiques pastorales, modernisation, délocalisation

nomsmotscles Tibétain, Ouighour

\section{AUTEUR}

\section{HERMANN KREUTZMANN}

Hermann Kreutzmann is Chair of Human Geography and Director of the Institute of Geographic Sciences at the Freie Universitaet Berlin. Research subjects are human-environmental relations in South and Central Asia, high mountain research, pastoralism and hydraulic resources, development studies, migration research and political geography.

h.kreutzmann@fu-berlin.de

Publications :

2009 Transformations of High Mountain pastoral strategies in the Pamirian Knot, Nomadic Peoples 13(2), pp. 102-123.

2008 Kashmir and the Northern Areas of Pakistan : Boundary-making along contested frontiers, 
Erdkunde 62(3), pp. 201-219.

2008 Dividing the World : Conflict and Inequality in the Context of Growing Global Tension, Third World Quarterly 29(4), pp. 675-689. 